\title{
The role of educator in food and nutrition by health professionals in the context of Family Health Care
}

\author{
A atuação de educador em alimentação e \\ nutrição pelos profissionais da saúde no \\ contexto da Saúde da Família
}

Fernanda Werbicky CARVALHO-GEBRAN ${ }^{1}$ (D) 0000-0001-8214-2480

Kellem Regina Rosendo VINCHA ${ }^{2}$ (D) 0000-0001-5806-0821

Ana Maria CERVATO-MANCUSO² (ID) 0000-0002-9276-8943

\section{A B S T R A C T}

\section{Objective}

This study aimed to understand the role of health professionals in educational groups that have food and nutrition as their theme.

\section{Methods}

Qualitative research was conducted in the city of São Paulo, with professionals from the Family Health Strategy. Interviews were conducted to understand the professionals' perceptions of the roles played in groups. These were analyzed using the Discourse of the Collective Subject technique. The groups' observations on the performance of the professionals in their mediations were analyzed, based on the following items: meeting organization, communication, support, participation, confirmation of messages, and encouragement to ask questions.

\footnotetext{
1 Universidade de São Paulo, Faculdade de Odontologia, Programa de Mestrado em Formação Interdisciplinar em Saúde. Av. Dr. Arnaldo, 175, 01246-904, São Paulo, SP, Brasil. Correspondência para/Correspondence to: FW CARVALHO-GEBRAN. E-mail:<fe.nutricionista@yahoo.com.br>.

2 Universidade de São Paulo, Faculdade de Saúde Pública, Departamento de Nutrição. São Paulo, SP, Brasil. Support: Conselho Nacional de Desenvolvimento Científico e Tecnológico (Process no 481712/2011-9).

Article based on the dissertation of FW CARVALHO-GEBRAN, entitled "Educação alimentar e nutricional na atenção primária à saúde na perspectiva do profissional não nutricionista”. Universidade de São Paulo; 2016.
}

Como citar este artigo/How to cite this article

Carvalho-Gebran FW, Vincha KRR, Cervato-Mancuso AM. The role of educator in food and nutrition by health professionals in the context of Family Health Care. Rev Nutr. 2018;31(1):71-81. https://doi.org/10.1590/1678-98652018000100007 


\section{Results}

Twenty-two professionals from different backgrounds were interviewed, and 23 groups of different configurations were observed. The speeches showed that the professionals recognize themselves as organizers, mediators, and evaluators of the groups. Under the topic of organization, teamwork was highlighted. In mediation, there was an assumption of different types of performance that are inserted in conceptions of banking education and dialogical education. In the theme of evaluation, conflict and contradiction arose, pointing out the complexity of approaching a group theme when professionals seek a more horizontal posture with users. Observation of the groups revealed a duality between discourse and professional practice, which is surrounded by contradictions inserted into academic formation and the work process of the teams.

\section{Conclusion}

It was possible to understand the complexity of the practice of professionals when approaching the theme in groups, evidencing the need for spaces of care and for permanent education, especially when regarding professionals who use problematic and active approaches.

Keywords: Food and nutrition education. Health personnel. Primary health care.

\section{R E S U M O}

\section{Objetivo}

O estudo teve por objetivo compreender o papel dos profissionais da saúde em grupos educativos que têm a alimentação e nutrição como temática.

\section{Métodos}

Trata-se de pesquisa qualitativa realizada na cidade de São Paulo, com profissionais da Estratégia Saúde da Familia. Conduziram-se entrevistas para compreender a percepção dos profissionais sobre os papéis exercidos em grupos. As respostas foram analisadas mediante técnica do Discurso do Sujeito Coletivo. Realizaram-se observações dos grupos quanto ao desempenho dos profissionais em suas mediações, sendo analisados os itens: organização do encontro, comunicação, apoio, participação, confirmação das mensagens e estímulo à realização de perguntas.

\section{Resultados}

Entrevistaram-se 22 profissionais de diferentes formações, observando-se 23 grupos de diferentes configurações. Os discursos mostraram que os profissionais se reconhecem como organizadores, mediadores e avaliadores dos grupos. Na organização, destacou-se o trabalho em equipe. Na mediação, houve a assunção de distintos desempenhos, inseridos em concepções da educação bancária e da dialógica. Na avaliação, surgiram conflitos e contradições, o que aponta a complexidade de se abordar a temática em grupo quando o profissional busca uma postura mais horizontal com os usuários. A observação dos grupos revelou dualidade entre o discurso e a prática profissional, a qual é permeada por contradições inseridas na formação acadêmica e no processo de trabalho das equipes.

\section{Conclusão}

Foi possivel compreender a complexidade da prática dos profissionais ao abordarem a temática em grupos, evidenciando a necessidade de espaços de cuidado e de educação permanente, sobretudo para os aqueles que utilizam abordagens problematizadoras e ativas.

Palavras-chave: Educação alimentar e nutricional. Pessoal de saúde. Atenção primária à saúde.

\section{N T RO D U C T I O N}

The promotion of Adequate and Healthy Nutrition (PAAS, Promoção da Alimentação Adequada e Saudável) is one of the guidelines of the National Policy on Food and Nutrition (NPFN) [1] in Brazil, and it integrates a strategic axis of the National Policy for the Promotion of Health [2]. The quest to develop the population to select and use the food resources available 
in the territories to satisfy their nutritional requirements and, consequently, the attainment of adequate and healthy nutrition, is the goal of Food and Nutrition Education (FNE) [3].

The effectiveness of the interventions of Food and Nutrition Education depends on several factors, as pointed out in a systematic review by Murimi et al. [4]. The authors reported that, in addition to the duration of the goals and the proper use of theoretical frameworks, the ability of interventions to produce the expected results depends on the support of the management of workplace and public policies.

In Brazil, health professionals working in the Family Health Strategy (FHS), the main form of organization of Basic Care, longitudinally accompany individuals of a delimited territory, which favors the development of Food and Nutrition Education interventions [5,6]. In a study by Vasconcelos and Magalhães [7], it was demonstrated that these interventions are carried out by professionals from different backgrounds, in particular through educational groups. This finding has been reinforced by other authors $[8,9]$ who emphasize the multidisciplinary and transdisciplinary actuation in the Food and Nutrition Education, since nutrition-related issues pervade the complexity inherent to health.

The educational groups are recognized by professionals as spaces of health education that facilitate the collective construction of knowledge and reflection on the reality experienced by participants $[10,11]$. The effectiveness of these groups on health is influenced by the organization, the role of the professionals, their motivation and leadership, the presence of dialog in meetings, and by the recognition of knowledge and affective, social, and health needs [11].

In addition, it is understood that these elements in the field of nutrition, aided by the professionals, influence the effectiveness of educational groups in the Promoção da Alimentação Adequada e Saudável. Thus, the objective of this study is to understand the role of those FHS professionals in educational groups that have food and nutrition as a theme.

\section{METHODS}

This field research was conducted with a qualitative approach with the intention of understanding the perceptions of health professionals regarding their performance in educational groups that address diet and nutrition; that is, how do they live, feel, and think about this phenomenon [12].

The study was conducted in the city of São Paulo, which has an organizational structure composed of the Municipal Health Department (MHD), 5 Regional Health Agencies (RHA), 24 Technical Health Supervisions (THS) and 453 Basic Health Units (BHU), with shared management with the Social Health Organizations [13].

The population elected to participate in the study consisted of professionals from the FHS, with the exception of the nutritionist, who agreed to voluntarily participate in the study, and who develop educational groups with the theme food and nutrition. The professionals were selected based on the nomination of BHU managers, which, in turn, had been nominated by the THS and RHA. This selection sought to encompass the five RHA.

Semi-structured interviews and systematic observation and data production techniques were used, which complemented each other to investigate elements of relationships, practices, complicities, and omissions regarding the development of educational groups by the professionals [12]. These were conducted by previously trained researchers at the BHU, from May 2013 to April 2014.

A roadmap of issues was used to conduct the interview; it had been previously tested and was composed of topics relating to the training and professional activity (year of graduation, post-graduation, course and year of 
completion, area of performance, function and description of activities) and the development of educational groups (role played by professional). The interviews were audio-recorded and fully transcribed and analyzed.

Systematic observation was held on the same day as the interview, using a roadmap comprising six items regarding the professional performance in the mediation of educational groups: organization of the meeting (beginning, middle and end), verbal and non-verbal communication, support in the resolution of everyday problems, ensuring the participation of all, confirmation of the messages, and encouragement to ask questions. The roadmap was applied to group meetings mediated by the participating professionals, with the consent of the users.

The data produced in the interviews in relation to the training of professionals were categorized into area of performance and achievement of post-graduate courses, and the year of completion was divided into time periods. The data on the role of professionals in groups were analyzed by means of the Collective Subject Discourse technique (CSD) [14]. The technique, based on the theory of social representations, supports individual testimonies for the construction of one or more words representing the collective. For the construction of the CSD, the following steps were taken: description of key expressions, survey of Central
Ideas $(\mathrm{Cl})$, groups of similar $\mathrm{Cl}$, and construction of CSD, written in the first person singular.

The data produced was systematized and grouped in the observations according to the six items outlined in relation to the performance of the professional. In these, the items that most corresponded to the professional's role in an educational intervention were identified.

This research was approved by the Ethics Committees of the Secretary of Health of the Municipality of São Paulo (SHM-SP) (Opinion $n^{\circ}$ 100/12 and 22/13) and the Faculdade de Saúde Pública da Universidade de São Paulo (Public Health School, University of São Paulo) (Opinion $n^{\circ}$ 48307).

\section{RES U L T S}

Altogether, 22 health professionals with distinct training were interviewed: 11 nurses, 3 doctors, 2 nursing assistants, 2 agents of environmental promotion, 2 physical education teachers, 1 speech therapist, and 1 physical therapist. 17 professionals had recently participated in professional development (in the last 10 years) in one or more post-graduate courses. Of these, 14 had attended courses related to the area of action, that is, in Public Health.

Regarding the perception of professionals about the role played in educational groups, referred to hereafter as "groups", there were eight $\mathrm{Cl}$, presented in Chart 1. The CSD uncovered

Chart 1. Roles identified by health professionals in groups that have food and nutrition as a theme, and the central ideas found. São Paulo (SP), Brazil, 2016.

\begin{tabular}{ll}
\hline Roles identified & Central Ideas \\
\hline Group Organizer & 1 - I think my role is to organize. \\
\hline & 2 - This is a role of transmission of knowledge. \\
& 3 - I think my role is to raise awareness. \\
& $4-$ I think that this is a promoter of health. \\
& 5 - I think that this role facilitates the issues that they bring. \\
& 6 - I think my work in the group is to create bonds. \\
\hline Group Mediator & 7 - I think this role generates change. \\
& 8 - I think this role is one of putting me in their place. \\
\hline
\end{tabular}


different perceptions that emerged in the identification of three key roles: Organizer, mediator, and evaluator. It also noted that these are part of the work process when professionals plan the educational intervention.

The "group organizer" was identified by the collective recognition as the subject in the role of organizing themes to be discussed in the groups, taking care to involve professionals from different backgrounds and include interests and desires of the participants, according to the CSD-Cl1 presented in Chart 2.

After the organization of the groups they are developed, which is done by the person known as the "group mediator"; this is a moment for the professionals to apply their skills for the users. In this role, different characteristics of the professionals were perceived: transmitter of technical knowledge, awareness creator, health promoter, action facilitator, and bond creator, which were verified in CSD-CI 2, 3, 4, 5 and 6, respectively, and are presented in Chart 3 .

A transmitter of technical knowledge is recognized as someone who possesses information about health and transmits it to users. The awareness creator acknowledges that users also have knowledge, and that, therefore, it is up to him to direct the groups so that such knowledge becomes a part of their attitude.

Chart 2. The role of group organizer in groups that have food and nutrition as a theme. São Paulo (SP), Brazil, 2016.

\begin{tabular}{ll}
\hline Central Idea & Collective Subject Discourse \\
\hline & $\begin{array}{l}\text { I think my role is to organize the topics that we will discuss, in addition to bringing in a professional in the area } \\
\text { of nutrition to strengthen and deepen the issues, and working with the literature on nutrition. But in order to }\end{array}$ \\
I think my role & $\begin{array}{l}\text { do so, for example, to make a healthy cake, it is necessary to help the staff who receives me here as they are } \\
\text { is to organize }\end{array}$ \\
$\begin{array}{l}\text { within the team: the community agents and the nursing assistants. Making a recipe is very good and attracts } \\
\text { more participants than theoretical knowledge. Today I see that I bring the things that they like, and I feel valued } \\
\text { (CSD-CI1). }\end{array}$
\end{tabular}

Chart 3. The role of group mediators, and their different performances, in groups that have food and nutrition as a theme. São Paulo (SP), Brazil, 2016

\begin{tabular}{ll}
\hline Central Ideas & The Collective Subject Discourse \\
\hline This is a role of knowledge & This is a role of guidance, due to the issue of technical, scientific, and theoretical knowledge. I am \\
transmission & $\begin{array}{l}\text { a multiplier of my knowledge to them. It is an important role, because they have many doubts, } \\
\text { and believe many myths, and I believe that if we weren't here, who would guide them? (CSD-CI2). }\end{array}$
\end{tabular}

I think my role is to raise awareness

I think that this is a role of health promoter

I think that this is a role that facilitates the issues that they bring
I think that my role in the group is fundamental for their awareness, because they often know how to act, but they don't have guidance, that direction, the formation of a plan so that they can have better health, regardless of medication itself. And with that, we will gradually change the habits of the patients, one step at a time (CSD-CI3).

In addition to education, which I think is even a little more important (laughs), promoter of health. I think that this is the word: promotion, because people get very stuck in education (laughs). Sometimes the exchange of experiences makes promotion much stronger than if I talk, talk, talk, just because I know, know, know (CSD-CI4).

We have to be attentive to the needs of the participants, to achieve goals and transmit what we want to transmit to them. I try to facilitate the anguishing issues that they bring, valuing common knowledge and trying to direct them. Never judging, but trying to be co-responsive for care, to the extent that I'm giving them more information (CSD-CI5).

I think my work in the group is My group work is extremely important, because we have created a nice bond with the patients. to create bonds We see them every week and this creates a friendship, a trust (CSD-CI6). 
The promoter of health, in turn, is perceived as an agent who induces the exchange of experiences between users and identifies health promotion as something positive in relation to the transmission of knowledge. Meanwhile, the action facilitator assumes the role of analyzing the users' needs, values, and knowledge, and guides the groups toward the achievement of their goals, in order to build co-responsibility for care. And, finally, the bond creator is valued for bringing health services closer to users through groups, holding frequent meetings that offer a relationship of trust.

The role of "group evaluator" was identified and perceived in two ways. First, this professional has the role of analyzing the results of the groups in relation to the dietary changes of users, CSD-CI7. In the second way that they were perceived, the professional is part of the analysis of nutrition as a user of the groups, demonstrating conflict between the roles, CSD-CI8. Both CSD are presented in Chart 4.

To complement the understanding of the role of professionals in groups, 23 meetings of different groups were observed, from groups belonging to programs such as the Glycemic Self-Monitoring Program (Secretary of Health of the Municipality of São Paulo, Brazil), to groups built by professionals based on the needs of the population. In the observation, the presence of one to five professionals was found, and the mediation was specific to one professional or shared between two. The number of users in groups ranged from 3 to 40, and the duration of the meetings from 10 to 140 minutes.
The presence of verbal and non-verbal communication in the groups was observed, reflected in the visual contact between professionals and users and in clear and understandable communication, without the use of technical terms. These elements were favored by the adoption of the wheel format as an intervention strategy in most groups. With the wheel format, the inclusion of daily problems of the users was also observed, but most information came from the professionals, since the participation of the users was reduced and unstimulated. Thus, it was noticed that the groups, in general, were mediated through a vertical relationship between educators and learners.

One weakness found in the observed groups was the mediation of the meeting, as very few had linear events, and it was not possible to identify a beginning, middle, and end of the meeting, which may undermine the achievement of the groups' objectives. In this sense, the professionals did not verify whether the messages worked into meetings were understood by users, and/or did not attempt to reinforce them.

\section{DISCUSSION}

The models of higher education in health in Brazil follow hospital-centered and specialized practices, away from the humanistic, psychological and sociological training, which is necessary for performance in Basic Care [15]. Thus, the finding

Chart 4. The role of group evaluator in groups that have food and nutrition as a theme. São Paulo (SP), Brazil, 2016.

\begin{tabular}{ll}
\hline Central Idea & Collective Subject Discourse \\
\hline $\begin{array}{l}\text { I think that it is a role that } \\
\text { generates change }\end{array}$ & $\begin{array}{l}\text { I work with a lot of desire for them to change. For me, change has to occur, but I feel frustrated, } \\
\text { I'll find that I'm talking and it does not produce any effect. Sometimes I scold them to start doing } \\
\text { things right [...] (CSD-CI7). }\end{array}$ \\
& $\begin{array}{l}\text { I try to do the most to allow them to change, even though I always hit the same button, I know } \\
\text { that it is difficult to change eating habits. I say to them: "Don't follow my model because I am not } \\
\text { I think this role is one of } \\
\text { putting me in their place }\end{array}$ \\
\hline
\end{tabular}


of a recent update of professionals in postgraduation courses in the Public Health area can contribute to the effectiveness of the groups, given that continuing education promotes the development of new professional skills [16].

To ensure that the groups take place, the professionals need, within the realm of planning, to organize them, which includes creating invitations for users, setting up a framework (place, day, time), developing an the objective, and deciding on themes, activities, and professionals/mediators [17]. Regarding the professionals, it was verified in the CSD-CI1 that a collective subject emphasizes team work, supporting the study of Odgers-Jewell et al. [10]. These authors verified, with professional group mediators, that teamwork has a positive impact on the effectiveness of the intervention in terms of professional support and patient care. However, it was observed in this study that teamwork is fragmented, showing that the presence of different professionals in the same space does not necessarily attain the aforementioned effects.

In the role of "group mediator", the existence of two Food and Nutrition Education paradigms was observed: the banking education model and dialogic education. In the banking education model, scientific information that must be transmitted by professionals to users, who are considered to be knowledge-free, is valued. Users are expected to modify their health behaviors based on the information $[6,18]$, which had been identified in the CSD-CI2. It should be noted that this paradigm follows the academic training of professionals, who tend to reproduce it in health services [15]. Banking education is also present in CSD-Cl4, in the section "because in education we get very stuck", in which it is perceived that the collective subject understands that its role is tethered to the responsibility of imposing knowledge. In addition, in this CSD, there is a gap between health education and health promotion; however, for health public policies $[2,5]$, which govern professional practice, they are complementary.
Through systematic observation, two aspects favoring the adoption of the banking education model were identified: the presence of many users (40) in the same meeting, and a short time (10 minutes) to complete the intervention. It is understood that these aspects alienate the professionals from users, causing the former to use a health preventative speech. With regard to the number of users, Odgers-Jewell et al. [10] recommend that health programs restrict the number of participants, thereby promoting the development and effectiveness of the groups.

Alternatively, the dialogical education is useful for professionals and users, since it allows for the inclusion of real needs $[18,19]$, making the education process more meaningful to those present. This education model was recognized in the CSD-CI5, given the presence of the sharing of knowledge and experiences, by means of a horizontal relationship achieved by the construction of bonds. In this logic, the findings indicate that the groups make up educational spaces that generate the responsibility for care, converging with the findings of a study conducted with mediators of Australian groups [10].

It was noted in CSD-Cl3 that problematizing the knowledge of users leads them to awareness, so that they discover the reasons not to apply it in everyday life, and, from the discovery of and reflection upon those reasons, implement changes in nutrition [20]. In this sense, the professionals have a crucial role in directing the action, because they encourage the sharing of knowledge, problematizing it with users, and systematize the new knowledge, so that the groups achieve their goals $[3,17]$. In the problematization, feelings can be mobilized $[3,18]$, and these are highlighted in the CSD-CI5, in which the collective subject intervenes with information and valuing of knowledge.

The Food and Nutrition Education, in the paradigm of dialogical education, requires intervention time because it is seen as a long and continuous process [3]. This process was 
affirmed in the CSD-CI3, in the sentence, "we are gradually changing the habits of the patients, one step at a time". This has implications for professionals planning the duration and frequency of meetings, which must be flexible and consistent with the needs of the participants $[6,21]$. The frequency of meetings was pointed out in the CSD-Cl6 as important for the construction of bonds between professionals and users. Bonds nurture the relationship of trust and cooperation and promote adherence and satisfaction of users $[16,22,23]$, impacting the effectiveness of the groups in Basic Care.

However, this flexibility requires the attention of professionals so that they do not lose the linearity of events and the objectives of the groups [17], as occurred in the majority of the observed meetings. It should be emphasized that using the wheel format, speaking the same language, using eye contact, and putting themselves in a position of equality highlights dialogical education, but also exposes the weaknesses of the professionals and health services, limiting the effectiveness of the groups.

The role of "group evaluator" was found in the CSD-CI7, in which the collective subject highlights the changes in users' behavior: "For me there has to be change, otherwise I feel frustrated. I'll think I'm talking and it's not having any effect". In this section, one can note the attribution of responsibility for change exclusively to users, which can produce unstable results, since the way in which users eat is also determined by economic and social factors [24]. Therefore, if professionals do not recognize the complexity of food choices, frustration can follow, according to the aforementioned passage.

In the group evaluation, professionals who yearn for a horizontal posture can equate themselves with users, causing a conflict of roles and divergence between recommending standards and following these standards in their lives, as established in the CSD-Cl8. According to Castro et al. [25], this divergence is commonly seen in the professionals given that their food choices have, in the same way, senses and meanings, and lead them to create answers to a social system which creates oppression in the name of equality, of aesthetics and health. Ellery et al. [26] reinforce the importance of professionals having skills for taking care of themselves, so that this difference does not echo in their interventions.

Hence, spaces of professional care and permanent education become important as measures of empowerment on the theme and on the role of group educator $[27,28]$, thus guaranteeing the qualification of the workforce, instituted by National Policy on Food and Nutrition [1]. The importance of the nutritionist in the Family Health Support Unit in this qualification is recognized; the nutritionist is recognized as the professional who has, through training, an understanding of the emerging socio-psychocultural dimensions of the relationship between man and food [8], contributing to overcoming the noted divergence. Thus, this nutritionist should have the ability to take care of the health of the teams he supports, to understand concepts about food and nutrition, and to train Food and Nutrition Education educators. The last one stands out due to the fact that the nutritionist has, in the Food and Nutrition Education training and as a guiding document, the Food and Nutrition Education Reference Framework for Public Policies [24].

The analysis of the CSD and observations revealed the duality between speech and professional practice. The search for the development of the qualification of the population to achieve adequate and healthy nutrition is present in the intentionality of professionals who are looking for different ways to promote it. However, these intentions, represented in discourse, are permeated by contradictions that are inserted in academic formation and in the process of team work. Emphasis is placed on the experiences, feelings, and thoughts of the professionals, and the emphasis is on the social relations present in the groups, which supports 
the systematic review by Schembri et al. [29], who found that these relationships are more important for the efficacy of groups than a focus on information regarding the theme.

\section{CONCLUSION}

The importance of health professionals in the Food and Nutrition Education is emphasized, because, although they have no specific training on the topic, they have a role in planning, mediating, and assessing groups that cover food and nutrition, which support the recommendations of current public health policies. In the group mediator role, professionals assume different performances, from transmitter of knowledge to bond creator, but bring the Food and Nutrition Education somewhat current in relation to health promotion. This gap between education and promotion deserves to be explored and overcome, and one possibility is the inclusion of more participatory approaches in the academic training of professionals, as well as permanent education. With experience in active educational processes, these professionals can reframe the perception of education, reproducing it in health services.

Being a group educator requires a rapport and a detachment from users, which is a hard balance to find, especially with issues of food and nutrition. It is important for the nutritionist to create permanent education spaces, mobilizing the rethinking of this role along with other FHS professionals, so that new forms of nutritional care can be incorporated.

\section{A C KNOWLEDGMENTS}

To FC BOTELHO, LDS GUERRA and LV TONACIO, for the production of data. To Conselho Nacional de Desenvolvimento Científico e Tecnológico for the research funding and to Coordenação de Aperfeiçoamento de Pessoal de Nivel Superior for the grant to the author KRR Vincha.

\section{CONTRIBUTORS}

FW CARVALHO-GEBRAN participated in the data analysis and interpretation and the initial drafting of the article. KRR VINCHA and AM CERVATO-MANCUSO participated in the conception of the study, analysis and interpretation of data and the final drafting of the article.

\section{REFERE NCES}

1. Ministério da Saúde (Brasil). Secretaria de Atenção à Saúde. Política nacional de alimentação e nutrição. Brasília: Ministério da Saúde; 2012.

2. Ministério da Saúde (Brasil). Secretaria de Vigilância em Saúde. Política nacional de promoção da saúde: PNaPS. Brasília: Ministério da Saúde; 2014. p.1-24

3. Cervato-Mancuso AM, Fiore EG, Redolfi SCS. Guia de segurança alimentar e nutricional. Barueri: Manole; 2015.

4. Murimi MW, Kanyi M, Mupfudze $T$, Amin MR, Mbogori T, Aldubayan K. Factors Influencing Efficacy of Nutrition Education Interventions: A systematic review. J Nutr Educ Behav. 2017;49(2):142-65.e1. http://dx.doi.org/10.1016/j.jneb.2016.09.003

5. Ministério da Saúde (Brasil). Secretaria de Atenção à Saúde. Política Nacional de Atenção Básica. Brasília: Ministério da Saúde; 2012 [acesso 2016 mar 4]. Disponível em: http://189.28.128.100/ dab/docs/publicacoes/geral/pnab.pdf

6. Vincha KRR, Cárdenas AP, Cervato-Mancuso AM, Vieira VL. Grupos de educação nutricional em dois contextos da América Latina: São Paulo e Bogotá. Interface: Comunic Saúde Educ. 2014 [acesso 2016 jun 19]; 18(50):507-20. Disponível em: http://www.scielo.br/scielo.php?script=sci_arttext \&pid=S1414-32832014000300507\&lng=pt\&nrm $=i s o \& t \operatorname{lng}=p t$

7. Vasconcelos ACCP, Magalhães R. Práticas educativas em segurança alimentar e nutricional: reflexões a partir da experiência da Estratégia Saúde da Família em João Pessoa, PB, Brasil. Interface: Comunic Saúde Educ. 2016 [acesso 2016 out 12];20(56):99-110. Disponível em: http://www.scielo.br/scielo.php?script=sci_arttext \&pid $=$ S1414-32832016000100099\&Ing=pt\&nrm =iso \&tlng=en

8. Vincha KRR, Santos AF, Cervato-Mancuso AM. Planejamento de grupos operativos no cuidado de usuários de serviços de saúde: integrando experiências. Saúde Debate. 2017 [acesso 2017 
nov 19];41(114):949-62. Disponível em: http:// www.saudeemdebate.org.br/UserFiles_Padrao/ File/RSD114-web final.pdf

9. França CJ, Carvalho VCHS. Estratégias de educação alimentar e nutricional na atenção primária à saúde: uma revisão de literatura. Saúde Debate. 2017 [acesso 2017 out 4];41(114):932-48. Disponível em: http://www.scielo.br/scielo.php? script=sci_arttext\&pid=S0103-11042017000300 932\&lng=pt\&tlng=pt

10. Odgers-Jewell K, Hughes R, Isenring E, Desbrow B, Leveritt M. Group facilitators' perceptions of the attributes that contribute to the effectiveness of group-based chronic disease self-management education programs. Nutr Diet. 2015; 72(4):347-55. http://doi.wiley.com/10.1111/1747-0080.12190

11. Nogueira ALG, Munari DB, Fortuna CM, Santos LF. Pistas para potencializar grupos na atenção primária à saúde. Rev Bras Enfermagem. 2016;69(5):964-71.

12. Minayo MCS, editor. O desafio do conhecimento. 14a ed. São Paulo: Hucitec; 2014.

13. Secretaria Municipal de Saúde (São Paulo). Coordenação da Atenção Básica. Estrutura e serviços da atenção básica. São Paulo: Secretaria Municipal de Saúde; 2011 [acesso 2016 mar 7]. Disponível em: http://www.prefeitura.sp.gov.br/ cidade/secretarias/saude/atencao_basica/index. php?p=1936

14. Lefèvre $F$, Lefèvre AMC, Teixeira JJV. O discurso do sujeito coletivo: uma abordagem em pesquisa qualitativa. Caxias do Sul: Educs; 2003.

15. Almeida Filho NM. Contextos, impasses e desafios na formação de trabalhadores em Saúde Coletiva no Brasil. Ciênc Saúde Colet. 2013 [acesso 2016 mar 13];18(6):1677-82. Disponível em: http://www.scielo.br/scielo.php?script=sci_arttext \&pid=S1413-81232013000600019\&lng=pt\&tlng $=p t$

16. Scherer MDA, Oliveira Cl, Carvalho WMES, Costa MP. Cursos de especialização em saúde da família: o que muda no trabalho com a formação? Interface: Comunic Saúde Educ. 2016 [acesso 2016 jun 6];20(58):691-702. Disponível em: http://www.scielo.br/scielo.php?script=sci_arttext \&pid=S1414-328320160003006 91\&lang=pt

17. Afonso MLM. Como construir uma proposta de oficina. In: Afonso MLM, editor. Oficinas em dinâmicas de grupo na área da saúde. 2a ed. São Paulo: Casa do Psicólogo; 2010. p.133-230.

18. Freire $P$, editor. Pedagogia da autonomia: saberes necessários à prática educativa. São Paulo: Paz e Terra; 2011.
19. Einloft ABN, Silva LS, Machado JC, Cotta RMM. Influência de intervenções educativas em perfis antropométricos, clínicos e bioquímicos e na percepção de saúde e doença de portadores de hipertensão arterial no contexto da Saúde da Família. Rev Nutr. 2016 [acesso 2016 out 20];29(4):529-41. Disponível em: http://www. scielo.br/scielo.php?script=sci_arttext $\&$ pid $=$ S14 15-5273 20160004005 29\&lng=pt\&tlng=pt

20. Boog MCF, editor. Educação em nutrição: integrando experiências. Campinas: Komedi; 2013.

21. Lawal M, Woodman A, Fanghanel J, Ohl M. Barriers to attendance at diabetes education centres: Perceptions of education providers. J Diabetes Nurs. 2017 [cited 2017 Aug 27];21(2):61-6. Available from: http://www.thejournalofdiabete snursing.co.uk/media/content/_master/4891/files/ pdf/jdn21-2-61-6.pdf

22. Heidemann ITSB, Wosny AM, Boehs AE. Promoção da saúde na atenção básica: estudo baseado no método de Paulo Freire. Ciênc Saúde Coletiva 2014 [acesso 2016 maio 1];19(8):3553-9. Disponível em: http://wnw.scielo.br/scielo.php?script=sci_arttext \&pid=S1413-81232014000803553\&lng=pt\&nrm =iso\&tlng=en

23. Arantes LJ, Shimizu HE, Merchán-Hamann E. Contribuições e desafios da estratégia saúde da família na atenção primária à saúde no Brasil: revisão da literatura. Ciênc Saúde Coletiva. 2016 [acesso 2016 jun 24];21(5):1499-510. Disponível em: http://www.scielo.br/scielo.php?script=sci_ arttext\&pid=S1413-81232016000501499\&lng= pt\&tlng=pt

24. Ministério de Desenvolvimento Social e Combate à Fome (Brasil). Marco de referência de educação alimentar e nutricional para as políticas públicas. Brasília: MDS; 2012.

25. Castro JBP, Carvalho MCVS, Ferreira FR, Prado SD. Faça o que eu digo, mas não faça o que eu faço! A décalage como ferramenta para compreensão de práticas corporais e alimentares. Rev Nutr. 2015 [acesso 2016 mar];28(1):99-108. Disponível em: http://www.scielo.br/scielo.php?script=sci_arttext_ pr\&pid=S1415-52732015010200003

26. Ellery AEL, Pontes RJS, Loiola FA. Campo comum de atuação dos profissionais da estratégia saúde da família no Brasil: um cenário em construção. Rev Saúde Coletiva. 2013 [acesso 2016 fev 2];23(2):415-37. Disponível em: http://www.scielo sp.org/scielo.php?script=sci_arttext \&pid=S010373312013000200006\&lng=en\&nrm=iso\&tlng=pt

27. Ricardi LM, Sousa MF. Educação permanente em alimentação e nutrição na estratégia saúde 
da família: encontros e desencontros em municípios brasileiros de grande porte. Ciênc Saúde Colet. 2015 [acesso 2016 abr 9];20(1):209-18. Disponível em: http://www.scielo.br/scielo.php? script=sci_arttext\&pid=S1413-81232015000100 209\&lng=pt\&tlng=pt

28. Botelho FC, Guerra LDS, Pava-Cárdenas A, Cervato-Mancuso AM. Estratégias pedagógicas em grupos com o tema alimentação e nutrição: os bastidores do processo de escolha. Ciênc Saúde Coletiva. 2016 [acesso 2016 ago 25];21(6):1889-98. Disponível em: http://www.scielo.br/scielo.php?
script=sci_arttext\&pid=S1413-812320160006018 89\&lng=pt\&nrm=iso\&tlng=em

29. Schembri L, Curran J, Collins L, Pelinovskaia M, Bell H, Richardson C, et al. The effect of nutrition education on nutrition-related health outcomes of Aboriginal and Torres Strait Islander people: A systematic review. Aust N Z J Public Health. 2016 [cited 2016 may 15];40(1):42-7.

Received: April 24, 2017

Final version: December 19, 2017

Approved: January 22, 2018 